\title{
A distinct tospovirus causing necrotic streak on Alstroemeria sp. in Colombia
}

\author{
Afshin Hassani-Mehraban • Marleen Botermans • \\ J. Th. J. Verhoeven · Ellis Meekes · Janneke Saaijer • \\ Dick Peters $\cdot$ Rob Goldbach $\cdot$ Richard Kormelink
}

Received: 13 October 2009/Accepted: 14 December 2009/Published online: 12 February 2010

(C) The Author(s) 2010. This article is published with open access at Springerlink.com

\begin{abstract}
A tospovirus causing necrotic streaks on leaves was isolated from Alstroemeria sp. in Colombia. Infected samples reacted positively with tomato spotted wilt virus (TSWV) antiserum during preliminary serological tests. Further analysis revealed a close serological relationship to tomato chlorotic spot virus (TCSV) and groundnut ringspot virus (GRSV). A major part of the S-RNA segment, encompassing the nucleocapsid $(\mathrm{N})$ protein gene, the $5^{\prime}$ untranslated region and a part of the intergenic region $3^{\prime}$ of the $\mathrm{N}$ gene, was cloned and sequenced. The deduced $\mathrm{N}$ protein sequence showed highest amino acid identity $(82 \%)$ to that of TCSV, indicating that the virus represents a new tospovirus species, for which the name Alstroemeria necrotic streak virus (ANSV) is coined. Phylogenetic analysis based on the $\mathrm{N}$ protein sequence revealed that this Alstroemeria-infecting tospovirus clustered with tospoviruses from the American continent. Frankliniella
\end{abstract}

R. Goldbach: Deceased.

The nucleotide sequence data reported in this manuscript have been deposited at the NCBI/GenBank under accession no. GQ478668.

A. Hassani-Mehraban · J. Saaijer · D. Peters .

R. Kormelink $(\square)$

Laboratory of Virology, Department of Plant Sciences,

Wageningen University, P.O. Box 629,

6700 AP Wageningen, The Netherlands

e-mail: Richard.kormelink@wur.nl

M. Botermans · J. Th. J. Verhoeven

Section of Virology, Plant Protection Service,

P.O. Box 9102, 6700 HC Wageningen, The Netherlands

E. Meekes

Naktuinbouw, P.O. Box 40, 2370 AA Roelofarendsveen,

The Netherlands occidentalis was identified as potential vector species for ANSV.

Colombia represents one of the most important countries for production and export of various ranges of cut flowers, with annual sales over 475 million US \$ [25]. Worldwide, Colombia has the largest Alstroemeria cultivation, with a production area exceeding 200 ha (Könst Alstroemeria BV). Native to South America, Alstroemeria is becoming an important ornamental plant worldwide [32]. So far, at least 12 viruses, belonging to the genera Carlavirus, $\mathrm{Cu}$ cumovirus, Fabavirus, Nepovirus, Potexvirus, Potyvirus, Tobamovirus, Tobravirus and Tospovirus have been reported to infect Alstroemeria sp. [13].

The genus Tospovirus contains the plant-infecting members of the Bunyaviridae, a family of primarily animal-infecting viruses [12]. The type member of this genus is tomato spotted wilt virus (TSWV), which has been studied extensively because of its economic impact and broad host range [14, 15].

Tospovirus particles are quasi-spherical, $80-120 \mathrm{~nm}$ in diameter and enveloped by a lipid membrane. They are propagatively transmitted by thrips (Thysanoptera, Thripidae) [12], of which the western flower thrips, Frankliniella occidentalis (Pergande) is the most important vector species of the 13 thrips species identified as a tospovirus vector $[9,26,28,34]$.

Tospoviruses contain a single-stranded, tripartite RNA genome $[10,11,20]$ of which the small (S) RNA segment encodes the nucleocapsid $(\mathrm{N})$ protein and a nonstructural $\mathrm{NS}_{\mathrm{S}}$ protein in an ambisense gene arrangement.

So far, 19 tospovirus species are recognised [3] based on nucleocapsid $(\mathrm{N})$ protein sequence identity (90\% threshold) and vector specificity [12]. Members of a few of them, i.e. 
Iris yellow spot virus (IYSV), Impatiens necrotic spot virus (INSV), Chrysanthemum stem necrosis virus (CSNV), and Calla lily chlorotic spot virus (CCSV) were initially isolated from ornamentals [2, 6, 21, 22]. Up to now, members of four tospovirus species, i.e. TSWV, INSV, IYSV $[1,13]$ and most recently tomato yellow ring virus (TYRV) [17, unpublished data] have been identified to infect Alstroemeria sp. Reports on TSWV-infected Alstroemeria sp. $\mathrm{cv}$. Rosario have described negative effects on stem growth and both quality and quantity of the inflorescences [16].

In 2008, a putative tospovirus was isolated from the Alstroemeria crop in Colombia. Infected plants displayed necrotic streak symptoms on leaves and stems (Fig. 1). Initial serological analysis using TSWV-specific antisera revealed a weak but clearly positive reaction in double antibody sandwich enzyme-linked immunosorbent assay (DAS-ELISA). To assess whether the Alstroemeria virus was a mixture of TSWV, GRSV and/or TCSV, the Alstroemeria isolate was inoculated onto three transgenic $N$. benthamiana seedlings harbouring a chimeric cassette containing partial $\mathrm{N}$ gene sequences of these three viruses and two additional Asian tospoviruses to confer multiple resistance based on RNA silencing [18]. The Alstroemeria isolate was able to infect the transgenic plants, suggesting that this isolate clearly diverged from TSWV, GRSV and TCSV. Plants that were singly inoculated with TSWV, GRSV or TCSV did not show any infection, as confirmed by DAS-ELISA. Since the Alstroemeria virus propagated on the transgenic lines was free from TSWV, GRSV and TCSV, leaf material from these plants was used as a source of Alstroemeria virus for further experiments. Here, we describe the identification and characterisation of this newly isolated tospovirus.

The Alstroemeria isolate and tospoviruses TSWV (BR01), GRSV (SA-05), TCSV (BR-03), and INSV (NL-07), which was used as a reference [8], were mechanically inoculated and serially passaged on $N$. benthamiana. To analyse its host range, at least three plants of several species were selected and mechanically inoculated with leaf extracts of infected $N$. benthamiana source material and scored for infection both visually and serologically (Table 1). The virus, like the reference tospoviruses, infected petunia and cucumber only locally, while vegetables like pepper and tomato became systemically infected. In contrast to TSWV, TCSV and GRSV, the Alstroemeria isolate caused severe top necrosis on $N$. benthamiana. Attempts to back-inoculate the virus onto nine different Alstroemeria cultivars failed, as was reported earlier with TSWV [31].

To assess the economic impact of the Alstroemeria isolate in Colombia, the incidence of this virus not only in Alstroemeria but also in other ornamentals as well as vegetables will have to be determined.

To analyse the Alstroemeria isolate serologically and differentiate it from members of established tospovirus species, a DAS-ELISA was performed [4] using antisera directed against TSWV, GRSV, TCSV and INSV nucleocapsid protein. To this end, leaf samples from infected $N$. benthamiana were ground in PBS-Tween 1:20 (w:v) and applied to an ELISA plate pre-coated with IgGs to the respective viruses. Both IgG and AP-conjugate were diluted 1:1,000 from a $1 \mathrm{mg} \mathrm{ml}^{-1}$ stock. Thirty minutes after the addition of AP-substrate, absorbance was measured at $405 \mathrm{~nm}$ using a FLUOstar OPTIMA (BMG LABTECH $\mathrm{GmbH}$, Offenburg, Germany) microplate reader. The Alstroemeria isolate clearly cross-reacted with antisera to TCSV, GRSV and TSWV, but not with that to INSV (Fig. 2).

To enable taxonomic classification of the Alstroemeria isolate, its $\mathrm{N}$ protein gene was cloned and sequenced. To this end, total RNA was extracted from infected $N$. benthamiana plants using Trizol Reagent (Invitrogen, Carlsbad, CA, USA) according to the manufacturer's instructions. Reverse transcription was performed on $2 \mu \mathrm{g}$ RNA using AMV reverse transcriptase (Promega, Corp. Madison, WI, USA) in the presence of primers J060 (5'CATGGATCCTGCAGAGCAATTGTGTCA- ${ }^{\prime}$, containing BamHI and PstI restriction sites [in boldface] and
Fig. 1 Alstroemeria plant showing necrotic streaks on the stems (left panel) and leaves (right panel) during natural infection by ANSV
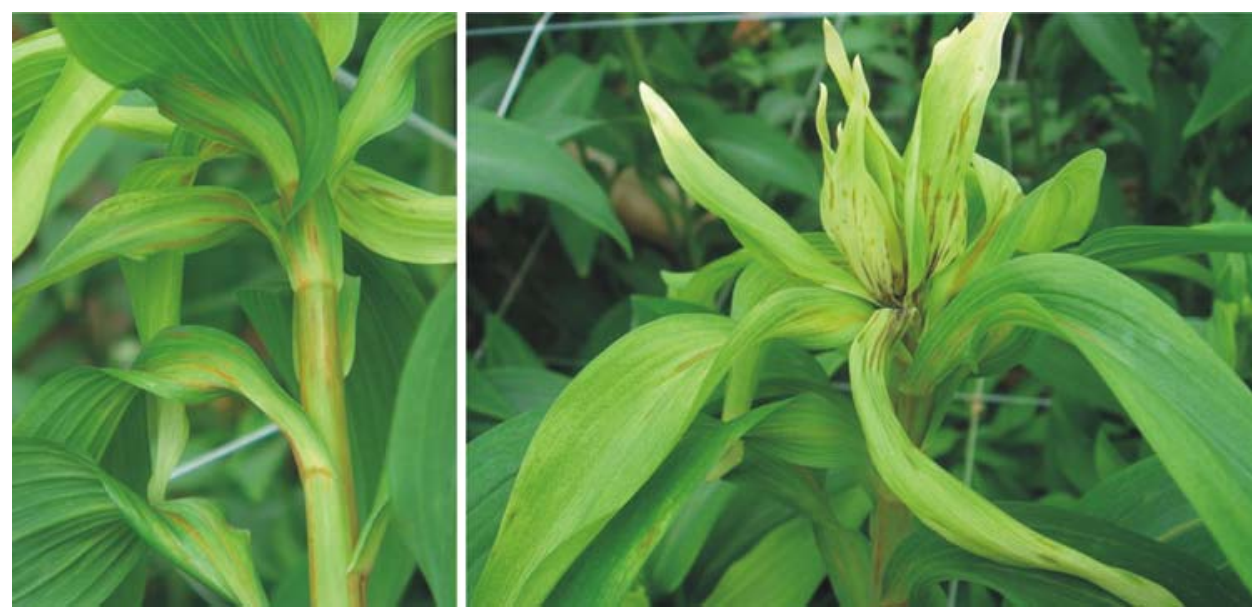
Table 1 Host range study of Alstroemeria necrotic streak virus

\begin{tabular}{|c|c|c|}
\hline \multirow[t]{2}{*}{ Plant family and species } & \multicolumn{2}{|l|}{ Symptoms } \\
\hline & Local & Systemic \\
\hline \multicolumn{3}{|l|}{ Balsaminaceae } \\
\hline Impatiens spp. & NL & - \\
\hline \multicolumn{3}{|l|}{ Asteraceae } \\
\hline Emilia sonchifolia & - & M \\
\hline \multicolumn{3}{|l|}{ Cucurbitaceae } \\
\hline Cucumis sativus & CL, NL & - \\
\hline \multicolumn{3}{|l|}{ Leguminosae } \\
\hline Glycine max cv. Sahar & - & - \\
\hline Phaseolus vulgaris & NL & $\mathrm{NL}, \mathrm{VN}, \mathrm{LD}, \mathrm{R}$ \\
\hline Vicia faba & BS & \\
\hline Vigna unguiculata & BS & - \\
\hline \multicolumn{3}{|l|}{ Liliaceae } \\
\hline Alstroemeria sp. cv. Dimension & - & - \\
\hline Lilium sp. cv. Gironde & - & - \\
\hline \multicolumn{3}{|l|}{ Solanaceae } \\
\hline Capsicum аппиит & CL & VC, Mo, D \\
\hline Datura stramonium & $\mathrm{CL}$ & $\mathrm{M}, \mathrm{NS}$ \\
\hline Nicotiana benthamiana & NL & $\mathrm{Ru}, \mathrm{C}, \mathrm{TN}$ \\
\hline N. glutinosa & NL & NS, TN \\
\hline N. occidentalis $-\mathrm{P} 1$ & NL & NL, PN \\
\hline N. rustica & CL & - \\
\hline N. tabacum White burley & CCR, CNR & VN \\
\hline Petunia hybrida & NL & - \\
\hline Physalis floridana & CL, NL & $\mathrm{VC}, \mathrm{M}, \mathrm{W}$ \\
\hline $\begin{array}{l}\text { Solanum lycopersicum cv. } \\
\text { Money maker }\end{array}$ & CL, NL & NL, NR, GR, R \\
\hline S. melongena & - & - \\
\hline
\end{tabular}

$B S$ brown spot, $C$ chlorosis, $C C R$ concentric chlorotic ring, $C L$ chlorotic lesion, $C N R$ concentric necrotic ring, $D$ dwarfing, $G R$ growth reduction, $L D$ leaf distortion, $M$ mosaic, $M o$ mottling, $N L$ necrotic lesion, $N R$ necrotic ring, $N S$ necrotic spot, $P N$ plant necrosis, $R$ recovery, $R u$ rugosity, $T N$ top necrosis, $V C$ veinal chlorosis, $V N$ veinal necrosis, $W$ wilting, - no symptoms

containing 15 nucleotides identical to the first 15 conserved nts of the $5^{\prime}$-end of the S RNA) and J064 (5'-CTT TGCTTTTCAGCACAGTGCA-3', complementary to $\mathrm{nt}$ 579-601 of the N gene of TSWV, TCSV and GRSV). After polymerase chain reaction (PCR) amplification using the same primers, a DNA fragment of expected size ( $\sim 700 \mathrm{bp}$ ) was amplified and cloned into pGEM-T Easy Vector (Promega Corp., Madison, WI, USA), and its sequence was analysed. Based on the partial $\mathrm{N}$ gene sequence obtained, an internal primer, Col-N-down (5'-GT GTTGTTCTGGCTATATACCAGG- $3^{\prime}$ ), was designed and used in combination with a universal hairpin primer (UHP) (5'-CACTGGATCCTTTTGTTTTTGTTTTTTG-3', containing a BamHI restriction site [in boldface]) to obtain the $3^{\prime}$ end of the $\mathrm{N}$ gene [7]. In this way, a partial S RNA sequence of 1,240 nucleotides was obtained, containing the entire open reading frame (ORF) of the $\mathrm{N}$ gene, flanked at one end by the $5^{\prime}$ untranslated region (UTR) sequence and at the $3^{\prime}$ end with a part of the intergenic region (IGR). The $5^{\prime}$ UTR of the $\mathrm{N}$ gene contained at its terminus the highly conserved consensus sequence of eight nucleotides that is found among isolates of all tospovirus species and assumed to play an important role in transcription/replication [19]. The $5^{\prime}$ UTR contained $152 \mathrm{nt}$ and showed the closest similarity (70\% identity) to the analogous region of TCSV. The sequenced partial IGR spanned $311 \mathrm{nt}$ and contained stretches highly rich in A and U residues, which is typical for the IGRs of tospoviral S RNA segments. The N ORF consisted of $777 \mathrm{nt}$, and its deduced protein sequence contained 258 amino acid residues (accession no. GQ478668). Multiple sequence alignment analysis, using Vector NTI (Invitrogen, Landsmeer, The Netherlands), showed that the Alstroemeria isolate was closely related to TCSV (82\%), GRSV (81\%) and TSWV (80\%) (data not shown), in agreement with their serological relationship, and suggested that the Alstroemeria isolate represents a new tospovirus species. Attempts to back-inoculate to Alstroemeria repeatedly failed, like previous attempts to mechanically inoculate TSWV onto Alstroemeria and to back-inoculate IYSV strains (IYSV $\mathrm{NL}_{\mathrm{NL}}$ and $\mathrm{IYSV}_{\mathrm{BR}}$ ) onto iris and onion [6, 27, 31]. For this reason, the Alstroemeria isolate has been provisionally named Alstroemeria necrotic streak virus (acronym ANSV). Data from a Clustal W alignment [30] of nucleocapsid $(\mathrm{N})$ protein sequences were used as input for phylogenetic analysis using MEGA version 4.0 software [29]. The results showed clustering of ANSV with TCSV, GRSV, and TSWV within the American tospovirus clade and support its origin from the American continent (Fig. 3).

Until now, five different thrips species, i.e. F. occidentalis, F. panamensis, F. auripes, F. minuta and Thrips tabaci, have been reported in Colombia. The first species has been observed on most flowers of all ornamental plants within greenhouse cultivations, whereas the second species is the most prevalent species outdoors [5]. Considering the fact that $F$. occidentalis, T. tabaci and F. schultzei are major vectors for viruses of the American tospovirus clade [24], the first two species, which are present in Colombia, were tested as candidate vectors of ANSV. To this end, ten 0-4 h old first instars of both F. occidentalis and T. tabaci were placed on two ANSV-infected Datura stramonium plants for virus acquisition [32]. Then thrips larvae were transferred onto healthy $D$. stramonium plants and kept there for $3 \mathrm{~h}$ to transmit the virus, and plants monitored for the next 2 weeks. Leaf samples were collected for total RNA extraction and subsequent RT-PCR analysis using primers J060 and J064. A fragment of about 700 bp was amplified from plants on which $F$. occidentalis had fed, and 
Fig. 2 Serological relationship between alstroemeria necrotic streak virus (ANSV) and four established tospovirus species belonging to the Americancontinent clade. Doubleantibody sandwich enzymelinked immunosorbent assay (DAS-ELISA) was performed using polyclonal antisera $(1: 1,000)$ raised against the $\mathrm{N}$ protein of each tospovirus and extracts from infected $N$. benthamiana plants $(1: 20)$ as antigen source. Absorbance values were recorded $30 \mathrm{~min}$ after addition of substrate
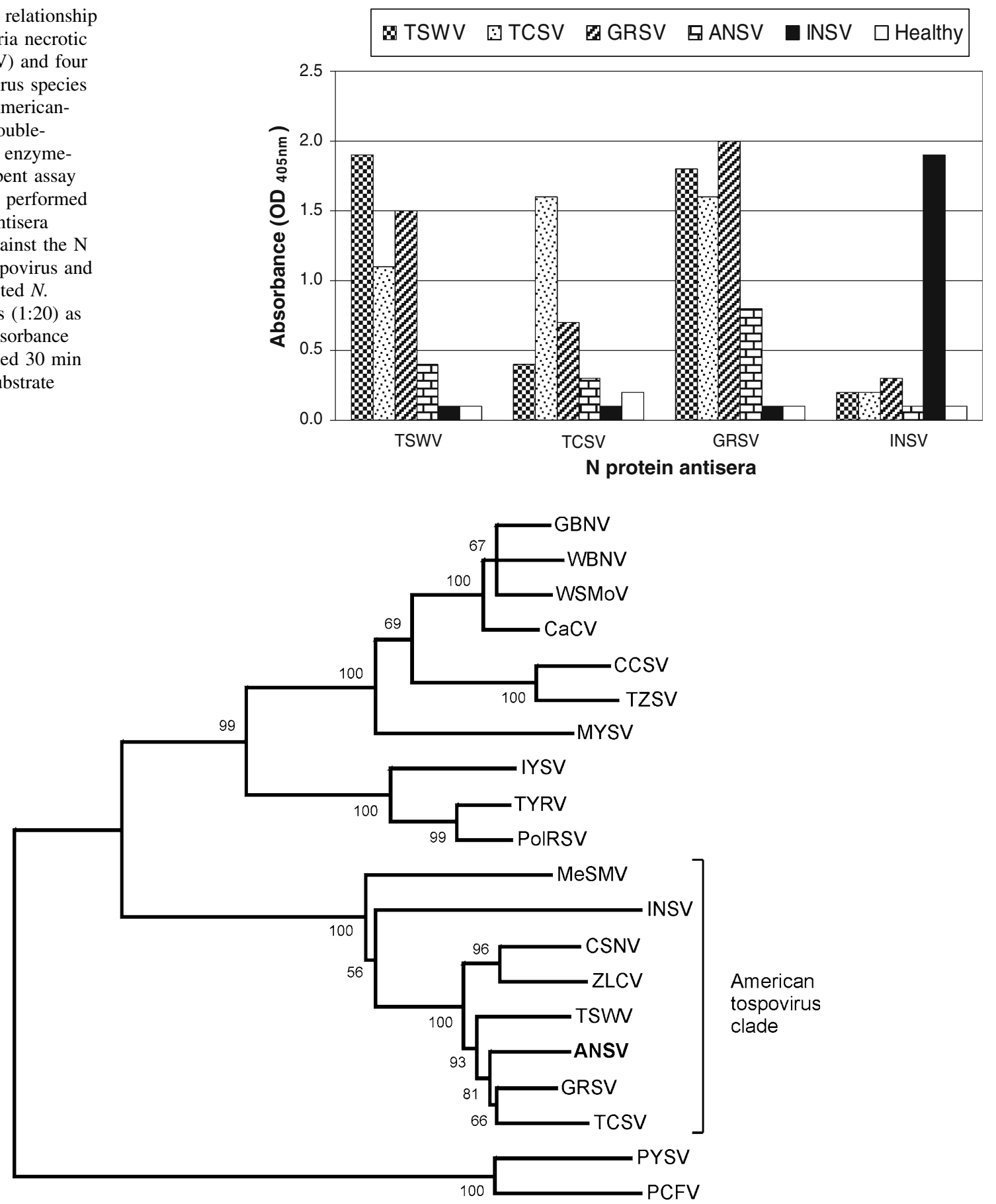

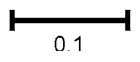

Fig. 3 Phylogenetic relationship of known tospoviruses based on the amino acid sequence of the $\mathrm{N}$ protein. The tree was constructed using the neighbour-joining method of MEGA version 4.0. Bootstrap values are shown as percentages derived from 1,000 replicates. Accession numbers (in parentheses) of the sequences are from GenBank: alstroemeria necrotic streak virus (ANSV) (GQ478668), capsicum chlorosis virus (CaCV) (AY036058), calla lily chlorotic spot virus (CCSV) (AY867502), chrysanthemum stem necrosis virus (CSNV) (AF067068), groundnut bud necrosis virus (GBNV) (U27809), groundnut ringspot virus (GRSV) (S54327), impatiens necrotic spot virus (INSV) (S40057), iris yellow spot virus (IYSV) (AF001387), melon severe mosaic virus (MeSMV) (EU275149), melon yellow spot virus (MYSV) (AF067151), peanut chlorotic fan-spot virus (PCFV) (AF080526), peanut yellow spot virus (PYSV) (AF013994), Polygonum ringspot virus (PolRSV) (EE445397), tomato chlorotic spot virus (TCSV) (S54325), tomato spotted wilt virus (TSWV) (D00645), tomato yellow ring virus (TYRV) (AY686718), tomato zonate spot virus (TZSV) (EF552433), watermelon bud necrosis virus (WBNV) (AF04567), watermelon silver mottle virus (WSMoV) (Z46419), zucchini lethal chlorosis virus (ZLCV) (AF067069) 
this was similar in size as the one amplified from ANSVinfected $N$. benthamiana positive-control plants. On the other hand, no fragment was amplified from plants exposed to $T$. tabaci or healthy $N$. benthamiana, suggesting that F. occidentalis is capable of transmitting ANSV (data not shown). Our attempts to thrips-transmit ANSV to Alstroemeria failed. The possibility that ANSV can also be transmitted by other vector species still remains to be investigated.

In Colombia, thrips are usually controlled by insecticides, but their abundance in greenhouses indicates that they have developed resistance against the insecticides used, and this diminishes the efficacy of such pest-management strategies [25]. Alternatively, these thrips species may have a stronger preference for Alstroemeria. As a consequence, the risk of exporting viruliferous thripsinfested plant material has become greater and concomitantly increases the threat of American tospoviruses to crops elsewhere in the world, e.g. of CSNV to Europe [23, 33], especially considering that some of their vectors, like F. occidentalis, are already present. The fact that Alstroemeria is vegetatively propagated additionally stresses the global importance of (local) disease management strategies to reduce the incidence of tospovirus infections.

In conclusion, the data presented in this report demonstrate that the Alstroemeria isolate represents a new tospovirus species for which, in light of the symptoms on its natural host, the name Alstroemeria necrotic streak virus (ANSV) is proposed. So far, the virus has not yet been reported either inside or outside of Colombia, possibly due to its (serological) misidentification as an isolate of TSWV, but this can now be tested (by RT-PCR) with the availability of the ANSV N gene sequence.

Acknowledgments The authors would like to acknowledge Könst Alstroemeria BV and Invitrogen Corp. for providing infected ANSV samples and different Alstroemeria sp. cultivars and Vector NTI Advance $^{\mathrm{TM}} 10$ license used in this study, respectively.

Open Access This article is distributed under the terms of the Creative Commons Attribution Noncommercial License which permits any noncommercial use, distribution, and reproduction in any medium, provided the original author(s) and source are credited.

\section{References}

1. Bellardi MG, Bertaccini A, Betti L (1994) Survey of viruses infecting Alstroemeria in Italy. Acta Hortic 377:73-80

2. Bezerra IC, Resende RO, Pozzer L, Nagata T, Kormelink R, de Ávila AC (1999) Increase of tospoviral diversity in Brazil with the identification of two new tospovirus species, one from chrysanthemum and one from zucchini. Phytopathology 89:823-830

3. Ciuffo M, Kurowski C, Vivoda E, Copes B, Masenga V, Falk BW, Turina M (2009) A new Tospovirus sp. in cucurbit crops in Mexico. Plant Dis 93:467-474
4. Clark MF, Adams AN (1977) Characterisation of the microplate method of enzyme linked immunosorbent assay for the detection of plant viruses. J Gen Virol 34:475-483

5. Corredor D (1999) Integrated pest management in cut flower crops grown in plastic houses at the Bogota plateau. Acta Hortic 482:241-246

6. Cortêz I, Livieratos IC, Derks A, Peters D, Kormelink R (1998) Molecular and serological characterisation of Iris yellow spot virus, a new and distinct tospovirus species. Phytopathology 88:1276-1282

7. Cortêz I, Saaijer J, Wongjkaew KS, Pereira A-M, Goldbach R, Peters D, Kormelink R (2001) Identification and characterisation of a novel tospovirus species using a new RT-PCR approach. Arch Virol 146:265-278

8. de Ávila AC, de Haan P, Smeets MLL, Resende RO, Kormelink R, Kitajima E, Goldbach R, Peters D (1992) Distinct levels of relationships between tospovirus isolates. Arch Virol 128:211227

9. de Borbón CM, Gracia O, Piccolo R (2006) Relationships between tospovirus incidence and thrips populations on tomato in Mendoza, Argentina. J Phytopathol 154:93-99

10. de Haan P, Kormelink R, Resende RO, van Poelwijk F, Peters D, Goldbach R (1991) Tomato spotted wilt virus L RNA encodes a putative RNA polymerase. J Gen Virol 72:2207-2216

11. de Haan P, Wagemaker L, Peters D, Goldbach R (1990) The S RNA segment of Tomato spotted wilt virus has an ambisense character. J Gen Virol 71:1001-1007

12. Fauquet CM, Mayo MA, Maniloff J, Desselberger U, Ball LA (2005) Virus taxonomy: eight report of the international committee on taxonomy of viruses. Elsevier Academic Press, San Diego

13. Fuji S-I, Mochizuki N, Fujinaga M, Ikeda M, Kouichi S, Seiji U, Hiromitsu F, Hideki N, Fumiyoshi F (2007) Incidence of viruses in Alstroemeria plants cultivated in Japan and characterisation of Broad bean wilt virus-2, Cucumber mosaic virus and Youcai mosaic virus. J Gen Plant Pathol 73:216-221

14. Goldbach R, Kuo G (1996) Introduction: Proceedings of the international symposium on tospovirus and thrips of floral and vegetable crops. Acta Hortic 431:21-26

15. Goldbach R, Peters D (1994) Possible causes of the emergence of tospovirus diseases. Semin Virol 5:113-120

16. Gutierrez-Estrada A, Zavaleta-Mejla E, Mora-Aguilera G (2000) Viruses associated to Alstroemeria varieties and epidemiology of Tomato spotted wilt virus in cv. 'Rosario'. In: 97th Annual International Conference of the American Society for Horticultural Science. Lake Buena Vista, FL, USA

17. Hassani-Mehraban A, Saaijer J, Peters D, Goldbach R, Kormelink R (2005) A new tomato-infecting tospovirus from Iran. Phytopathology 95:852-858

18. Hassani-Mehraban A, Brenkman AB, van den Broek NJF, Goldbach R, Kormelink R (2009) RNAi-mediated transgenic tospovirus resistance broken by intraspecies silencing suppressor protein complementation. Mol Plant Microbe Interact 22:12501257 javascript:popRef('c1')

19. Kormelink, R (2010) The molecular biology of tospoviruses and resistance strategies. In: Elliott RM, Plyusin A (eds) The Bunyaviridae. Plenum Press, New York. (in press)

20. Kormelink R, de Haan P, Meurs C, Peters D, Goldbach R (1992) The nucleotide sequence of the M RNA segment of tomato spotted wilt virus, a bunyavirus with ambisense RNA segment. J Gen Virol 73:2795-2804

21. Law MD, Moyer JW (1990) A tomato spotted wilt-like virus with a serologically distinct $\mathrm{N}$ protein. J Gen Virol 71:933-938

22. Lin YH, Chen T-C, Hsu H-T, Liu F-L, Chu F-H, Chen C-C, Lin Y-Z, Yeh S-D (2005) Serological comparison and molecular characterisation for verification of Calla lily chlorotic spot virus 
as a new tospovirus species belonging to Watermelon silver mottle virus serogroup. Phytopathology 95:1482-1488

23. Mumford RA, Jarvis B, Morris J, Blockely A (2003) First report of Chrysanthemum stem necrosis virus (CSNV) in the UK. Plant Pathol 52:779

24. Nagata T, Almeida ACL, Resende RO, de Ávila AC (2004) The competence of four thrips species to transmit and replicate four tospoviruses. Plant Pathol 53:136-140

25. Nicholls CI, Parrella MP, Altieri MA (1998) Advances and perspectives in the biological control of greenhouse pests with special reference to Colombia. Integr Pest Manage Rev 3:99-109

26. Ohonishi J, Katsuzaki H, Tsuda S, Sakurai T, Akutsu K, Murai T (2006) Franklliniella cephalica, a new vector for Tomato spotted wilt virus. Plant Dis 90:685

27. Pozzer L, Bezerra IC, Kormelink R, Prins M, Peters D, Resende RO, de Ávila AC (1999) Characterisation of a tospovirus isolate of iris yellow spot virus associated with a disease in onion fields in Brazil. Plant Dis 83:345-350

28. Premachandra WTSD, Borgemeister C, Maiss E, Knierim D, Poehling HM (2005) Ceratothripoides claratris, a new vector of a Capsicum chlorosis virus isolate infecting tomato in Thailand. Phytopathology 95:659-663
29. Tamura K, Dudley J, Nei M, Kumar S (2007) MEGA4: Molecular Evolutionary Genetics Analysis (MEGA) software version 4.0. Mol Biol Evol 24:1596-1599

30. Thompson JD, Higgins DG, Gibson TJ (1994) CLUSTAL W: Improving the sensitivity of progressive multiple sequence alignment through sequence weighting, position-specific gap penalties and weight matrix choice. Nucleic Acids Res 22:46734680

31. van Zaayen A (1995) Alstroemeria. In: Loebenstein G, Lawson RH, Brunt AA (eds) Virus and virus-like diseases of bulb and flower crops. Wiley, Chichester, pp 237-249

32. Van de Wetering F, Goldbach R, Peters D (1996) Tomato spotted wilt tospovirus ingestion by first instar larvae of Frankliniella occidentalis is a prerequisite for transmission. Phytopathology 86:900-905

33. Verhoeven JTJ, Roenhorst JW, Cortês I, Peters D (1996) Detection of a novel tospovirus in chrysanthemum. Acta Hortic 432:44-51

34. Whitfield AE, Ullman DE, German TL (2005) Tospovirus-thrips interactions. Ann Rev Phytopathol 43:459-489 